\title{
Environmental Stresses Induced by Salinity/Alkalinity in the Carpathian Basin (Central Europe)
}

\author{
Gy. VÁRALLYAY \\ Research Institute for Soil Science and Agricultural Chemistry (RISSAC) of the \\ Hungarian Academy of Sciences, Budapest
}

Soils represent a considerable part of natural resources. Consequently, rational land use and soil management - to ensure normal soil functions - are important tasks of sustainable development. Salinity/alkalinity/sodicity are significant environmental stresses in the Carpathian Basin situated in Central Europe (including Hungary and certain parts of Croatia, Romania, Slovakia, Ukraine and Yugoslavia). These natural or human induced stresses result in an increasing ecological hazard to the biosphere; limit the agro-ecological potential and represent a considerable socio-economic risk for sustainable development (KOVDA \& SZABOLCS, 1979; SZABOLCS, 1971, 1979).

\section{Salinization/Alkalization Processes}

Water as solvent, reactant and transporting agent is an important factor of the development of salt affected soils (SZABOLCS \& VÁRALLYAY, 1981).

In addition to local weathering products, saline surface waters and poor quality irrigation waters, subsurface waters have a particular role in the formation of salt affected soils (SZABOLCS et al., 1976). Groundwater is the main source of $\mathrm{Na}^{+}$, especially in low-lying, poorly drained areas in the hydrogeologically closed Carpathian Basin. Here:

- the horizontal flow of groundwater is extremely slow (small slope gradient $\rightarrow$ hydraulic gradient, and generally very low hydraulic conductivity) and this "stagnant" character leads to increasing salt concentration;

- the water table is near to the surface, thus capillary flow can transport relatively high quantities of water and soluble salts from the groundwater to the overlying horizons, to the root zone.

Correspondence to: Dr. György VÁRALLYAY, Research Institute for Soil Science and Agricultural Chemistry (RISSAC) of the Hungarian Academy of Sciences, H-1022 Budapest, Herman Ottó út 15. Hungary. E-mail: g.varallyay@rissac.hu 
The climate in the lowland part of the Carpathian Basin can be characterized by $500-550 \mathrm{~mm}$ mean annual precipitation versus a $750-800 \mathrm{~mm}$ yearly potential evaporation. Both show extremely high spatial and time variability. The negative water balance is particularly expressive during the summer months: June 60/120 mm, July 50/140 mm, August 50/110 mm (VÁRALlYAY, 1994). This water deficit is equilibrated by surface runoff, seepage in the unsaturated zone and groundwater flow from the neighbouring territories, practically from the whole water catchment area to the deepest parts of the Basin with poor natural drainage. It leads to the accumulation of the transported weathering products of the large watershed within a relatively small territory of the Basin.

As an example, two representative salt profiles are presented in Figure 1 (SZABOLCS, 1971, 1979).

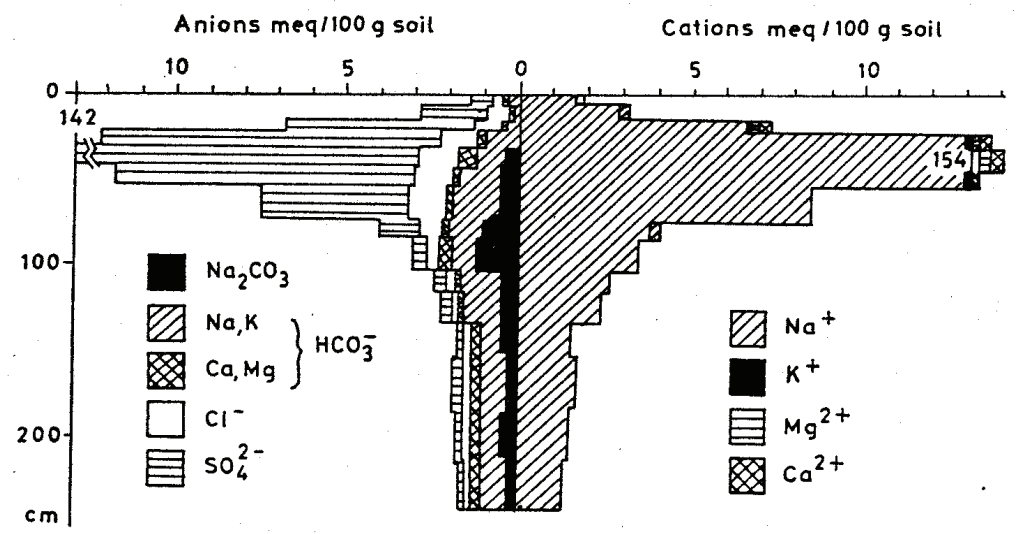

Hortobágy - Profile 2

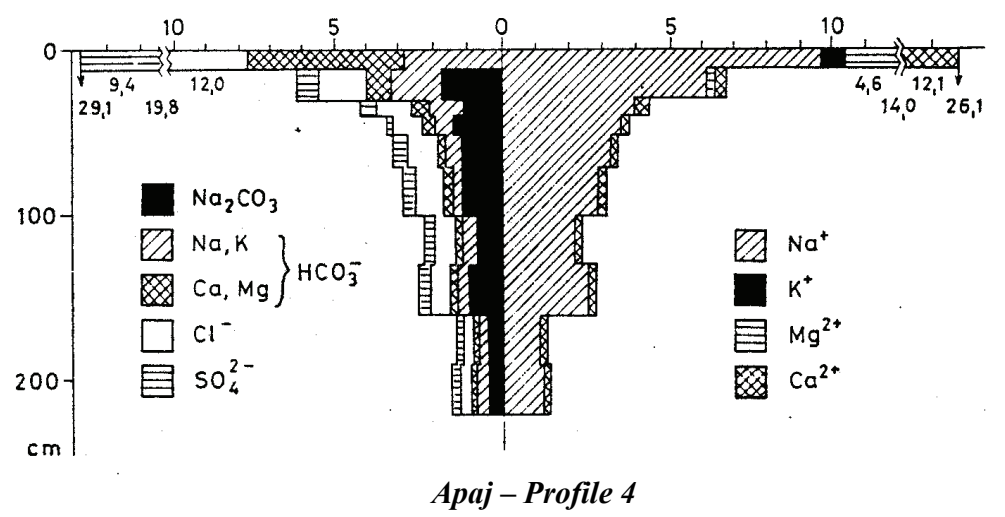

Figure 1

Water soluble salt content of the 1:5 aqueous extract

Hortobágy - Profile 2 (meadow solonetz soil) and Apaj - Profile 4 (solonchak soil) 
In the region there is a very close correlation between the micro-relief, the depth of water table, the salinity of groundwater and the significance and characteristics of soil salinity.

For the exact and quantitative characterization of the salt regime (salt content, salt profile, salt composition, salt dynamism) SZABOLCS, DARAB and VÁRALLYAY (1976, 1980) efficiently applied the "factorial salt balances", introduced the term "critical depth" of the groundwater table (preventing unfavourable salt accumulation in soil from poor-quality, saline groundwater) and elaborated a four-step model for the quantification of water and solute transport in stratified soil profiles above the fluctuating water table (SZABOLCS et al., 1976; VÁRALLYAY \& MIRONENKO, 1979; VÁRALLYAY \& RAJKAI, 1989).

In the major part of the Carpathian Basin - because sodium-carbonate(bicarbonate)-type salinity is predominant - the soil solution is always alkaline (frequently strongly alkaline), consequently most of the $\mathrm{Ca}$ - and $\mathrm{Mg}$-salts (mainly carbonates and bicarbonates) are present in precipitated form, and only the more soluble Na-salts remain in solution. The absolute and relative predominance of $\mathrm{Na}^{+}$in this migrating soil solution results in a high $\mathrm{Na}^{+}$saturation of soil absorption complex even at relatively low salt concentration.

In Figure 2 the exchangeable cation composition is presented for the two representative salt affected soil profiles.
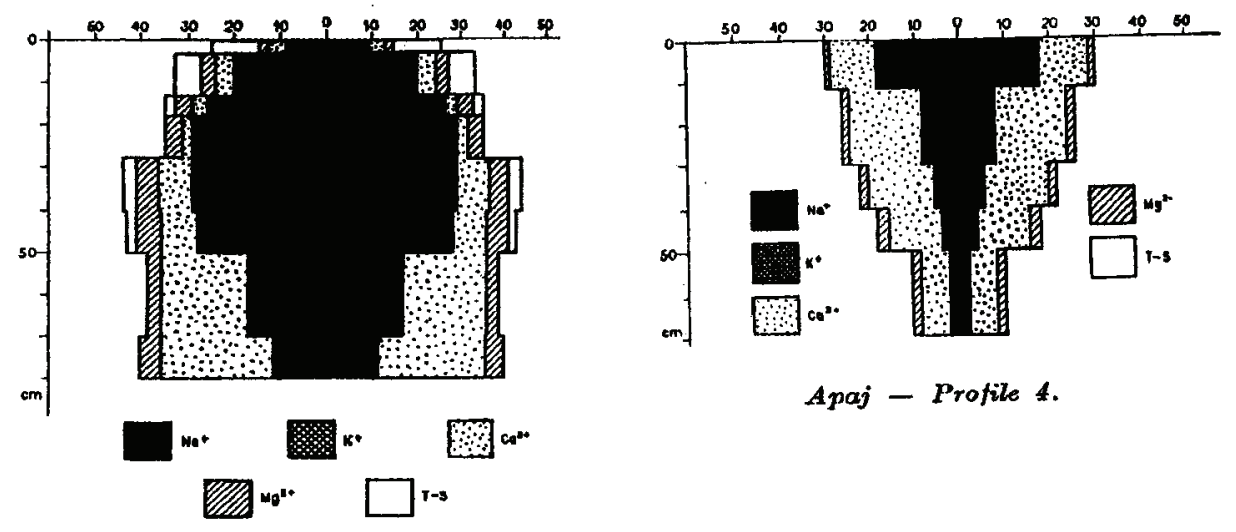

Hortobágy - Profile 2.

Figure 2

Exchangeable cation composition (meq/100 g soil) in the representative soil profiles Hortobágy - Profile 2 (meadow solonetz soil) and Apaj - Profile 4 (solonchak soil) 


\section{Influence of Salinity/Alkalinity/Sodicity on the Physical Properties and Moisture Regime of Soils}

High Na saturation brings about unfavourable (sometimes radical and near to irreversible) changes in the physical and hydrophysical properties of salt affected soils and the extreme moisture regime becomes their main ecological stress factor.

Soil salinity-alkalinity exerts considerable influence on the:

- mineralogical status (degradation, destruction and formation of clay minerals, orientation of clay particles, etc.) of the soil;

- rate of hydration and dispersion of soil colloids;

- swelling-shrinkage-cracking phenomena;

- arrangement of primary particles, shape, size and stability of soil micro- and macro-aggregates, structural elements, consequently the pore-size distribution pattern;

- factors of soil moisture regime: spatial (vertical and horizontal) and time distribution of moisture content, moisture potential and moisture movement (vapour transfer, saturated and unsaturated flow, etc.).

These interactions are summarized in Figure 3 (VÁRALLYAY, 1980, 1981).

The main soil factors limiting the optimum (adequate and continuous) water supply of plants in salt affected soils can be divided into three major groups:

- limited water storage capacity (due to limited infiltration);

- cracking (swelling-shrinkage phenomena);

- low availability of soil moisture.

These factors are schematically summarized in Figure 4. In the case of a surface crust or a compact soil layer near to the surface not only root penetration is impeded but infiltration is also limited, which creates an extreme moisture regime:

- oversaturation ( $\rightarrow$ aeration problems $\rightarrow$ anaerobic biological processes $\rightarrow$ reduction $\rightarrow$ decreasing availability of plant nutrients), temporary waterlogging and surface runoff ( $\rightarrow$ lateral erosion) after rainfall or irrigation;

- drought-sensitivity $(\leftarrow$ limited water storage capacity + high evaporation losses) during dry periods, even under irrigated conditions (Figure 4).

Crack formation in swelling clays causes another water problem in heavytextured solonetz soils (Figure 3).

The alkalization (high $\mathrm{Na}^{+}$saturation) of soils, especially of heavy-textured soils with high swelling clay content, causes increased hydration, swelling, dispersion of soil colloids, aggregate and structure destruction, and clogging of macropores, i.e. significant (sometimes radical) changes in pore size distribution: pore size and macropore volume decrease while "total porosity" (increasing volume due to swelling and constant mass $\rightarrow$ decreasing bulk density) and 


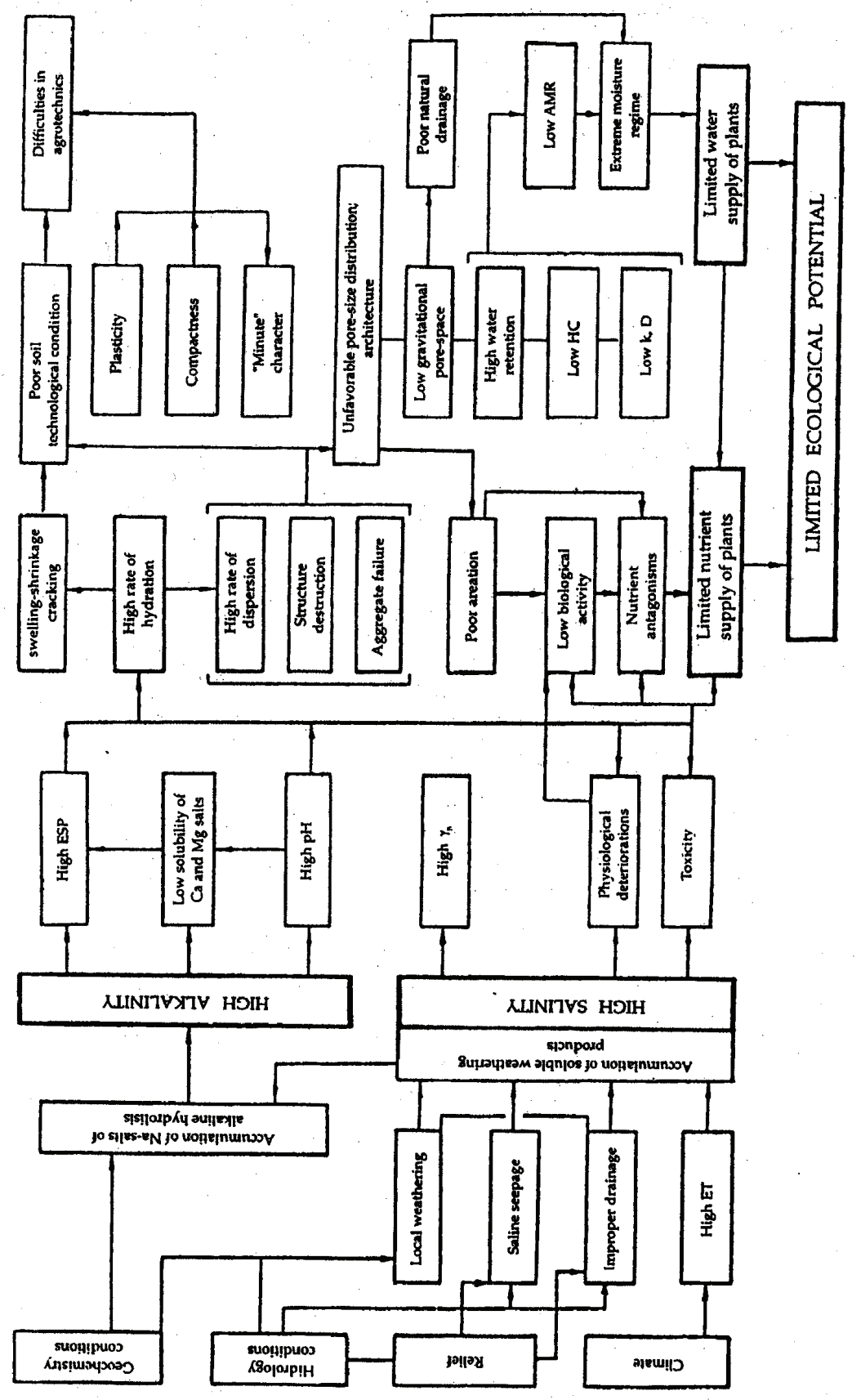

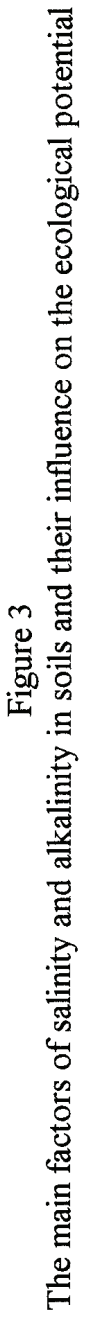



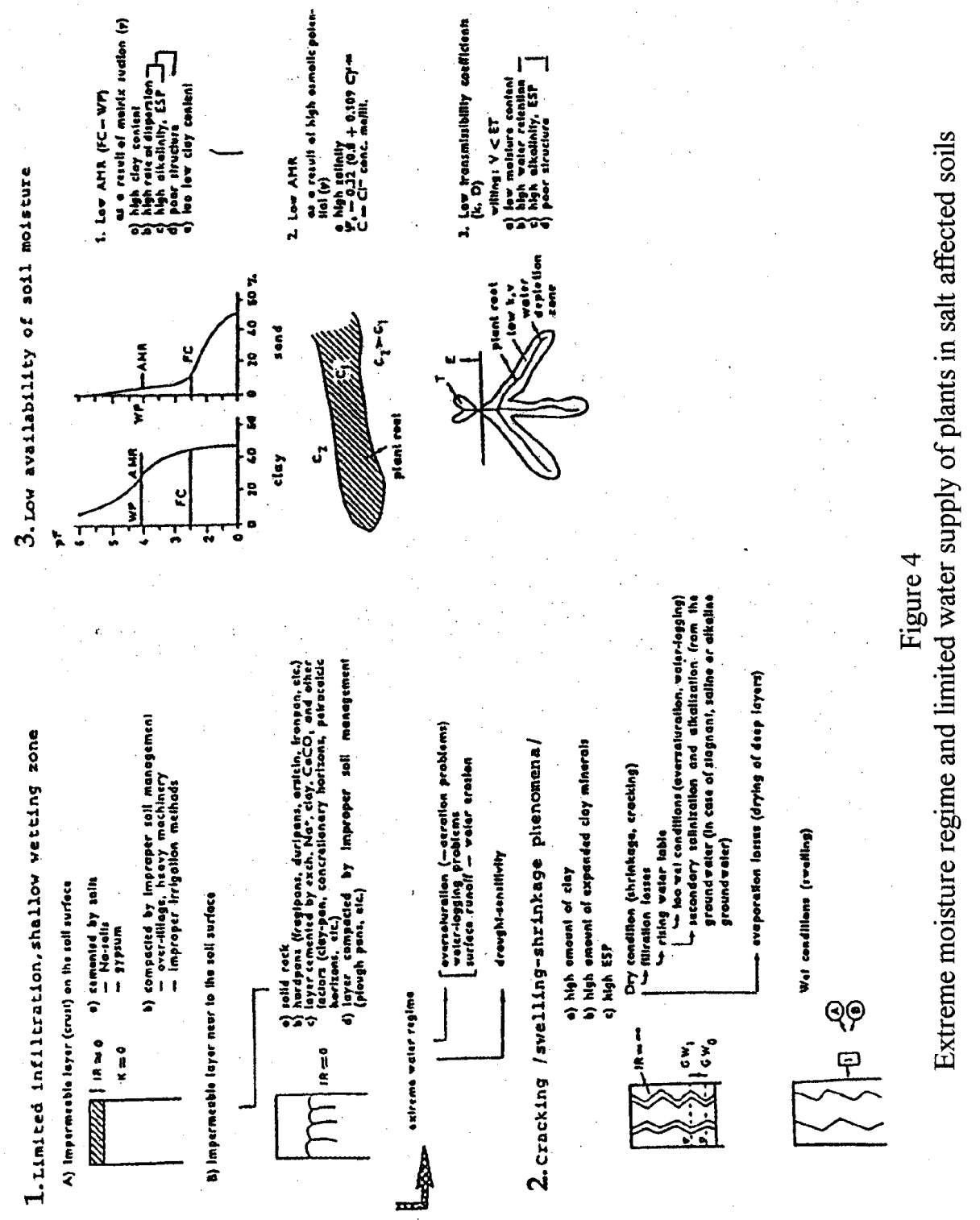
macropore volume (filled by strongly bound "immobile", "semi-solid state" water) increases.

Generally, it can be stated that, as a consequence of increasing ESP

- water retention increased within the whole suction range;

- gravitational pore space decreased (due to the above-mentioned large pore

$\rightarrow$ fine pore size redistribution).

Saturated hydraulic conductivity $(K=\mathrm{cm} /$ day) depends primarily on the geometry (size, shape), spatial arrangement and continuity of soil pores. In salt affected soils it is influenced mainly by structure destruction (high amount of exchangeable $\mathrm{Na}^{+} \rightarrow$ increasing hydration $\rightarrow$ swelling, deformation and dispersion of soil aggregates) and by particle movement ( $\rightarrow$ clogging of macropores). At low $\mathrm{Na}^{+}$saturation $\mathrm{K}$ depends mainly on ESP, whereas in coarse-textured soils $\mathrm{K}$ values are correlated mainly with clay content.

$\mathrm{K}$ values are presented as a function of filtration time for the various horizons of a solonchak (M-11 from the Hungarian Danube Valley, Kiskunság, Apaj) and a shallow meadow solonetz (M-14 from the Hungarian Plain, TransTisza region, Hortobágy) (Figure 5) (VÁRALlYAY, 1997).

In many cases low transport coefficients (capillary conductivity, $\mathrm{k}$; diffusivity, D) are responsible for the inadequate water supply of plants. In many

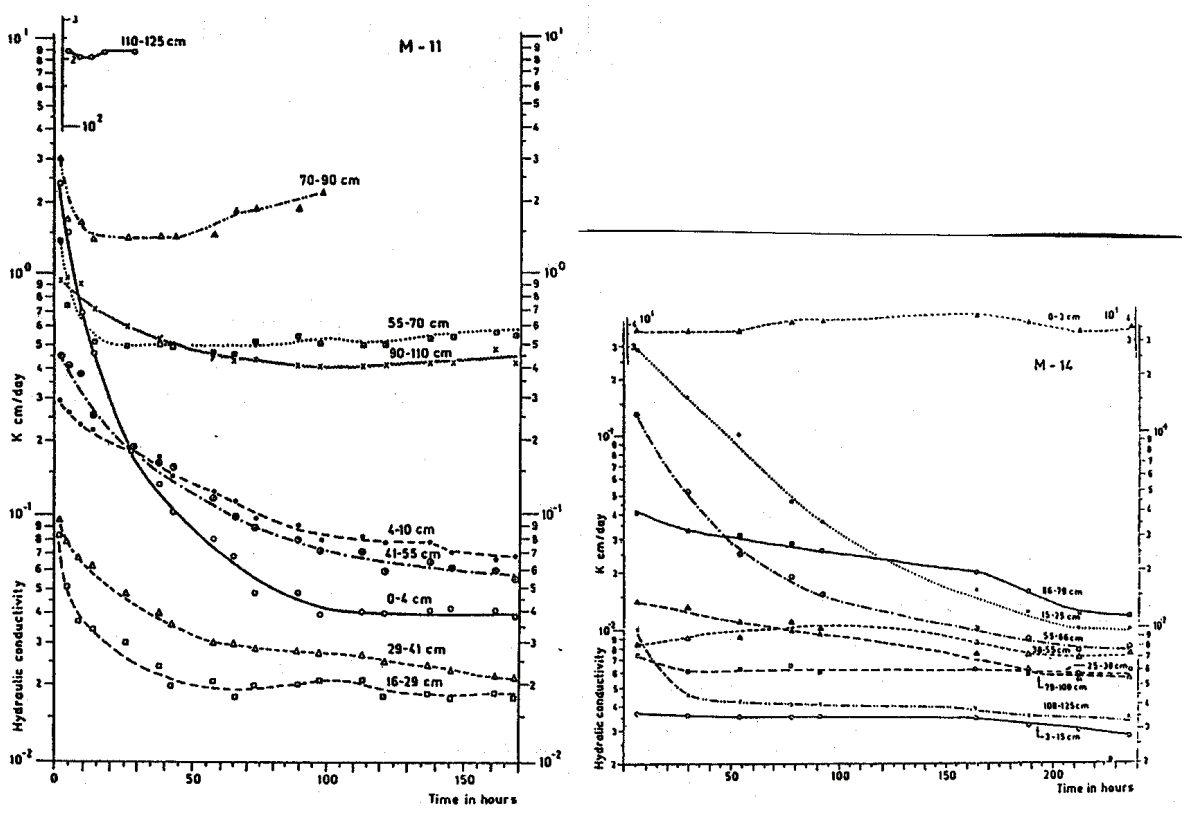

Figure 5

Permeability curves for the horizons of a solonchak (M-11) and a shallow solonetz (M-14) from the Hungarian Plain 
heavy-textured salt affected soils the flux from the wet soil to the plant roots - in spite of the high suction gradient - is extremely slow through the thin but rather dry "film-like" moisture depletion zone, formed around the plant roots. As a consequence of this, there is a peculiar micro-distribution pattern of soil moisture and the water supply of plants (especially of crops with a widelyspaced, scarce root system) is strongly limited, influencing water deficiency stress (physiological drought) (VÁRALlYAY, 1981, 1997; VÁRALlYAY \& MiRONENKO, 1979).

In Figure 6 the results of a model experiment are summarized. Hydraulic conductivity decreased under the influence of increasing ESP, especially in saturated conditions, and in the low suction range. The rate of k-decrease with increasing suction was moderated with increasing ESP ("n" decreased). The influence of high alkalinity (ESP) gradually decreased with increasing suction: it was only moderate in the medium suction range ( $\mathrm{pF}$ 2.7-4.0), and in the high suction range (at $\mathrm{pF} 4.5-5.0$ ) the $\mathrm{k}$-values proved to be similar in all the variants $\left(\approx 1-3 \times 10^{-6} \mathrm{~cm} /\right.$ day). In such soils infiltration and downward flow (wet conditions, low gradient) are more limited than the upward capillary flow (dry conditions, high gradient) promoting progressive salinization and alkalization in the presence of a shallow, saline $\left(\mathrm{Na}_{2} \mathrm{CO}_{3}\right)$ groundwater. These unfavourable changes cannot be balanced by the traditional leaching and drainage techniques, but need complex ameliorative measures (VÁRALLYAY, 1997).

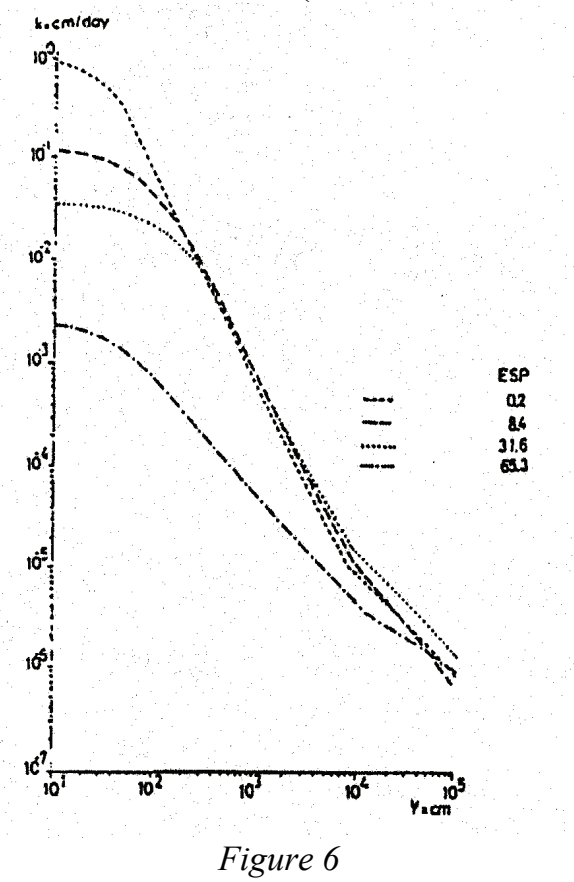

Relation between capillary conductivity $(\mathrm{k}=\mathrm{cm} /$ day $)$ and suction $(\Psi=\mathrm{cm})$ in a clay loam saturated with sodium to various degrees 


\section{Control of Soil Salinity/Alkalinity-induced Stresses}

A quantitative soil degradation assessment system has been elaborated in Hungary during the last two decades on the basis of all available soil information and experimental results, including the application of (geo)statistical analyses, simulation- and predictive transport and transformation models, as well as, the integration of remote sensing and GIS techniques. The assessment was the basis of an "early-warning system" giving possibilities for the efficient control of soil processes, for the prevention of harmful environmental stresses and their undesirable ecological/economical/social consequences. The required site-specific management activities are necessary elements of sustainable development harmonizing agricultural production and environment protection for a long time.

\section{Summary and Conclusions}

In the hydrogeologically closed Carpathian Basin subsurface waters have particular importance in the salinization/alkalization processes. In the poorlydrained low-lying areas the capillary flow transports high amounts of water soluble salts from the shallow, ,stagnant" groundwater with high salt concentration and unfavourable sodium-carbonate(bicarbonate) type ion composition to the overlying soil horizons. Due to the strongly alkaline soil solution, the $\mathrm{Ca}$ and $\mathrm{Mg}$ salts (mostly carbonates and bicarbonates) are not soluble and $\mathrm{Na}^{+}$ became absolutely predominant in the migrating soil solution which leads to high ESP even at relatively low salt concentration. High $\mathrm{Na}^{+}$saturation of heavy-textured soils with high amount of expanding clay minerals results in unfavourable physical-hydrophysical properties and extreme moisture regime of these soils, which are their main ecological constrains and the limiting factors of their fertility, productivity and agricultural utility. The simultaneous hazard of waterlogging or overmoistening, and drought sensitivity in extensive lowland areas, sometimes in the same places within a short period, necessitates a precise, "double function" soil moisture control against their harmful ecological/ economical/social consequences.

Most of the environmental constrains (including salinity/alkalinity/sodicity) can be efficiently controlled: prevented, eliminated, or - at least - moderated. But this needs permanent care and proper actions: adequate soil and water conservation practices based on a comprehensive soil/land degradation assessment. It includes continuous registration of facts and changes (monitoring); exact and quantitative knowledge on the existing soil processes, their influencing factors and mechanisms.

Key words: salinity/alkalinity; environmental stresses; degradation assessment; extreme moisture regime; control of soil processes 


\section{References}

Kovda, V. A. \& SzabolcS, I. (Eds.), 1979. Modelling of Soil Salinization and Alkalization. Agrokémia és Talajtan. 28. Suppl.

SzABOLCS, I. (Ed.), 1971. European Solonetz Soils and Their Reclamation. Akadémiai Kiadó. Budapest.

SzABOLCS, I., 1979. Review on Research of Salt Affected Soils. UNESCO. Paris.

Szabolcs, I. \& VÁrallyay, G., 1981. Problems of soil salinity and alkalinity in watersheds. Acta Agron. Hung. 80. (1-2) 249-266.

Szabolcs, I., VÁrallyay, Gy. \& DARAB, K., 1976. Soil and hydrologic survey for the prognosis and monitoring of salinity and alkalinity. In: Prognosis of Salinity and Alkalinity. (Report of an Expert Consultation, Rome, 3-5 June, 1975) Soil Bulletin No. 31. 119-129. FAO. Rome.

Szabolcs, I., Darab, K. \& VÁrallyay, Gy., 1980. Pronostico y prevencion de la salinizacion secundaria de las tierras irrigadas. Ciencias de la agricultura. (6) 109130.

VÁrallyay, Gy., 1980. Agro-ecological potential and its limitation by salinity and alkalinity. In: Int. Symp. on Salt Affected Soils, Karnal, India, 1980. 476-486. CSSRI. Karnal.

VÁRALLYAY, GY., 1981. Extreme moisture regime as the main limiting factor of the fertility of salt affected soils. Agrokémia és Talajtan. 30. Suppl. 73-96.

VÁrallyay, GY., 1994. Climate change, soil salinity and alkalinity. In: Soil Response to Climate Change. (Eds.: Rounsevell, M. D. A. \& Loveland, P. J.) NATO ASI Series. 1. Vol. 23. 39-54. Springer-Verlag, Heidelberg.

VÁRALlYAY, GY., 1997. Salinity/alkalinity as limiting factors of soil productivity in the Carpathian Basin. In: Proc. Trans-National Meeting: „Salinity as a factor for agricultural productivity in the Mediterranean Basin”, Naples, March 24-25, 1997. 23-41. INRC-ONR-CIHEAM. Naples.

VÁRALlyay, GY., 1997. Physical/hydrophysical limitations in salt affected soils in the Carpathian Basin. In: Proc. Int. Symp. on Sustainable Management of Salt Affected Soils in the Arid Ecosystem and FAO-Workshop on Integrated Management of Sustainable Use of Salt-Affected Soils, Cairo. 148-168.

VÁrallyay, Gy. \& MironenKo, E. V., 1979. Soil-water relationships in saline and alkali conditions. Agrokémia és Talajtan. 28. Suppl. 33-82.

VÁRALlYAY, GY. \& RAJKAI, K., 1989. Model for the estimation of water (and solute) transport from the groundwater to overlying soil horizons. Agrokémia és Talajtan. 38. 641-656. 